\title{
Identification of Lactic Acid Bacteria from Fermented Young Muskmelon (Cucumis melon Linn)
}

\section{Norng Chakriya ${ }^{1 *}$, Dizon I Erlinda ${ }^{2}$, Elegado B Francisco ${ }^{3}$, Huon Thavrak ${ }^{1}$, Ang Vichheka ${ }^{1}$, Ly Sokheng ${ }^{1}$, Prom Kimheang ${ }^{1}$, Rith Sokuncharya ${ }^{1}$, Masataka Uchino ${ }^{4}$ and Chay Chim $^{1}$}

${ }^{1}$ Royal University of Agriculture, Phnom Penh, Cambodia

${ }^{2}$ Institute of Food Science and Technology, College of Agriculture and Food Science, University of the Philippines Los Baños, College, Philippines

${ }^{3}$ The National Institute of Molecular Biology and Biotechnology (BIOTECH), University of the Philippines Los Baños, College, Philippines

${ }^{4}$ Department of Molecular Microbiology, Faculty of Life Science, Tokyo University of Agriculture, Japan

*Corresponding Author: Norng Chakriya, Royal University of Agriculture, Phnom Penh, Cambodia.

DOI: 10.31080/ASNH.2020.05.0817
Received: December 02, 2020

Published: January 21, 2021

(C) All rights are reserved by Norng Chakriya., et al.

\begin{abstract}
Fermentation has been used since ancient times as an easy method of vegetables' preservation, which also maintains and improves the nutritional and sensory properties of the final products. The lactic acid bacteria (LAB) involved in fermentation are generally recognized as safe. Lactic acid bacteria are a group of Gram positive, non-respiring, non- spore forming, cocci or rod, which produce lactic acid as the major end product of the fermentation of carbohydrate. This study isolated LAB from naturally-fermenting young muskmelon (Cucumis melon $\operatorname{Lin} n$ ) in $10 \%$ brine solution at pre-determined time intervals using the standard pour plating technique. A total of 18 isolates were chosen and purified by streak plating on MRS agar medium and incubated at $37^{\circ} \mathrm{C}$ for $24-48 \mathrm{~h}$. Physiological and biochemical characterization of the isolates were carried out. Fermentation of carbohydrates was determined using the API 50 CHL System. Results of the study revealed that out of the three (3) strains of selected LAB strains; one strain was identified as Lactobacillus brevis while the two strains are Pediococcus pentosaceus. These LABS are potential inoculants for commercial production of fermented fruits and vegetables.
\end{abstract}

Keywords: Lactic Acid Bacteria; Fermentation; Cucumis melon Linn; Lactobacillus brevis; Pediococcus pentosaceus

\section{Introduction}

Fermentation is one of the oldest methods of food preservation. It is the process of conversion of sugars to acids by microorganisms [1]. Fermented vegetables are good appetizers, consumed by people of all ages and contain large amounts of lactobacilli which are important for the digestion of grains and vegetables, and have beneficial probiotic properties [2]. Fermented vegetables prepared by lactic acid bacteria (LAB) fermentation have unique flavor and beneficial health effects [3]. LAB in fermented vegetables help to enhance human nutrition by providing vitamins, minerals, and carbohydrates, and produce various aroma components, organic acids, enzymes, bacteriocins, and exopolysaccharides. These metabolic products impart some characteristic properties such as taste, texture and longer shelf life to the products [4]. LAB carries out detoxification of toxic compounds and degradation of mycotoxins in specific cases and therefore can reduce the health risk. Lactic acid bacteria are considered as safe additives and Generally Recognized as Safe (GRAS), useful to control the frequent development 
of pathogens and spoilage microorganisms in food and feed [5]. The microorganisms involved in the fermentation of fermented vegetables have been identified as Lactobacillus plantarum, L. brevis, Leuconostoc mesenteroides, Pediococcus cerevisiae, Pediococcus pentosaceus and Enterococcus faecalis [3,6]. The LAB isolated from fermented young muskmelon (Cucumis melon Linn) differ from other microorganisms as they can tolerate considerably high concentration of salt and sugar. So far, there is no information about the lactic acid bacteria from brine-fermented young muskmelon $(\mathrm{Cu}$ cumis melon Linn). Keeping this in view, the present study aimed to isolate and identify useful lactic acid bacteria from fermented young muskmelon (Cucumis melon Linn).

\section{Materials and Methods}

- Samples: The spontaneously fermenting young muskmelon (Cucumis melon Linn) in 10\% brine solution; and samples were taken after $24 \mathrm{~h}$ and 3-5 days interval thereafter until 20 days for microbial analysis. The processing was conducted in food bioprocessing laboratory of Faculty of AgroIndustry, Royal University of Agriculture (RUA), Phnom Penh, Kingdom of Cambodia.

- Isolation of Lactic Acid Bacteria (LAB): Samples were taken at pre-determined time intervals for a period of 20 days. The standard dilution plating technique was carried out wherein $0.1 \mathrm{ml}$ of the appropriate dilutions of the sample was pour plated on de Man Rogosa and Sharpe (MRS) agar medium with $1 \% \mathrm{CaCO}_{3}$ and incubated at $37^{\circ} \mathrm{C}$ for $24-$ $48 \mathrm{hrs}$ [7]. Colonies were randomly selected based on their morphological appearance and streak plating was then used to purify the isolates. The individual bacterial colonies were stored in MRS agar stab at $4^{\circ} \mathrm{C}$ for further analysis.

- Physiological and Biochemical characterization: The purified isolates were further characterized on the basis of their biochemical tests i.e. tolerance at different $\mathrm{NaCl}$ concentrations $(3 \%, 5 \%, 8 \%, 11 \%$, and $14 \%)$; growth at different pHs (3.0, 4.0 and 5.0); and growth at different temperatures $\left(10^{\circ} \mathrm{C}\right.$ and $\left.45^{\circ} \mathrm{C}\right)$.

- Identification of Lactic Acid Bacteria: Fermentation of carbohydrates was determined using API $50 \mathrm{CHL}$, a standardized system, consisting of 50 biochemical tests for the study of carbohydrate metabolism by microorganisms. API $50 \mathrm{CH}$ is used in conjunction with API 50 CHL medium for the identification of Lactobacillus according to the manufacturer's instructions (Biomerieux, Marcy l' Etoile, France) [8]. Ten (10) $\mathrm{ml}$ of distilled water was dispensed into the incubation box with the strips placed in it, after the bacterial cultures had been introduced into the API 50 CHL system in API 50 CHL medium ( $5 \mathrm{ml}$ ), at concentration of $2 \mathrm{McF}$ arland. The set-up of the system was then incubated at appropriate temperature of $35^{\circ} \mathrm{C}$ for $48 \mathrm{~h}$, after which the wells were filled with the bacterial suspensions at the line mark with the addition of mineral oil. Bacterial strains were identified based on their ability for carbohydrates fermentation. Identification of isolates was carried out based on the color change of API strips reaction and recorded as + or - . Numerical profiles of strains were identified adding positive values in indicative table. Species designations were identified by evaluating with software identification Apiweb TM.

\section{Results and Discussion}

After proper selection of acid-forming bacteria (Figure 1) and purification (Figure 2), the isolates were subjected for physiological and biochemical tests. Results revealed that Lactic acid bacteria (LAB) isolates are all Gram-positive (+), non-spore forming, either rod- or cocci-shaped, catalase (-), oxidase (-), and acid-tolerant (Table 1). After proper characterization, the selected isolates were tested for their ability to ferment various carbohydrates using the API 50 CHL test kit. There are identified as: Lactobacillus brevis 1, Pediococcus pentosaceus 1, and Pediococcus pentosaceus 1 (Table 2).

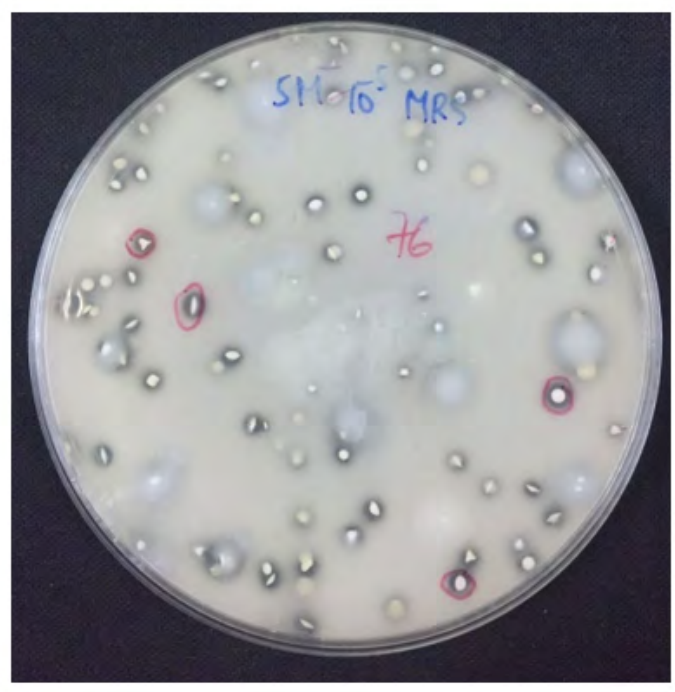

Figure 1: Plate showing clearing around colonies of acid-forming bacteria on $\mathrm{MRS}+\mathrm{CaCO}_{3}$ agar plate. 


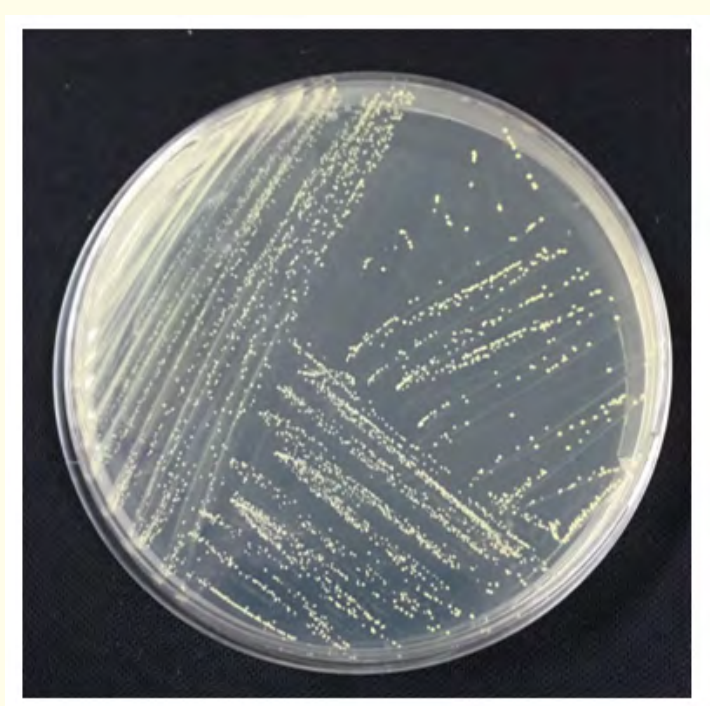

Figure 2: Plate showing discrete colonies of subculture LAB isolate.

Eighteen bacterial strains were isolated from different phases of the fermentation of young muskmelon (cucumis melon Linn), however only four bacterial strains have tolerance to high salt concentration and high temperature (Table 1); and these were characterized by the API 50 CHL System of identification (Table 2). The cultural characteristics of the isolates are shown in table 3 . Three of the isolates were identified as Lactobacillus brevis, and two as Pediococcus pentosaceus.

Lactobacillus brevis is a species of lactic acid bacteria, all of which are Gram-positive, non-spore forming organisms whose main metabolic pathway involves fermenting hexose sugars to produce lactic acid. Along with other lactic acid-producing bacteria, L. brevis plays an integral role in the fermentation of certain foods such as sauerkraut and pickles and is likewise the most common cause of spoiled beer. In fact, in Germany at one point, more than half of beer spoilage incidents were due to L. brevis alone. L. brevis can be isolated from the food sources in inhabits, one example being kimchi [9].

Pediococcus pentosaceus are coccus shaped microbes, Grampositive, non-motile, non-spore forming, and are categorized as a "lactic acid bacteria". P. pentosaceus are categorized as a "lactic acid bacteria" because the end product of its metabolism is lactic acid [10]. P. pentosaceus, like most lactic acid bacteria, are anaero-

\begin{tabular}{|c|c|c|c|c|c|c|c|c|c|c|c|}
\hline \multirow{2}{*}{ Code } & \multirow{2}{*}{ Gram } & \multirow{2}{*}{ Shape } & \multirow{2}{*}{ Catalase } & \multirow{2}{*}{ Oxidase } & \multicolumn{5}{|c|}{$\mathrm{NaCl}(\%)$} & \multicolumn{2}{|c|}{ Temperature $\left({ }^{\circ} \mathrm{C}\right)$} \\
\hline & & & & & 3 & 5 & 8 & 11 & 14 & 10 & 45 \\
\hline $2 \mathrm{M} 5 \mathrm{a}$ & + & rod & - & - & $* * *$ & $* * *$ & $* * *$ & $* * *$ & $*$ & $* *$ & $* *$ \\
\hline $3 \mathrm{M} 7$ & + & coccus & - & - & $* * *$ & $* * *$ & $* * *$ & $* * *$ & * & $* *$ & $* *$ \\
\hline $7 \mathrm{M} 5 \mathrm{c}$ & + & coccus & - & - & $* * *$ & $* * *$ & *** & $* * *$ & * & $* *$ & *** \\
\hline $20 \mathrm{M} 5$ & + & coccus & - & - & $* * *$ & $* * *$ & $* * *$ & $* * *$ & $*$ & $* *$ & $* * *$ \\
\hline
\end{tabular}

Table 1: Physiological, biochemical characteristics, and phenotypic properties of lactic acid bacteria isolated from brine-fermented muskmelon (Cucumis melon Linn).

Note: *, Minimum Growth; **, Moderate Growth; ***, Maximum Growth; -, No Growth

bic and ferment sugars. Since the end product of metabolism is a kind of acid, $P$. pentosaceus are acid tolerant. They can be found in plant materials, ripened cheese, and a variety of processed meats [11]. P. pentosaceus is industrially important due to its ability as a starter culture to ferment foods such as various meats, vegetables, and cheeses [12]. P. pentosaceus bacteria is being cultured and researched for its ability to produce an antimicrobial agent (bacteriocins) as well as its use in food preservation [12]. P. pentosaceus can be cultured at $35{ }^{\circ} \mathrm{C}-40{ }^{\circ} \mathrm{C}$ but are unable to grow at $50{ }^{\circ} \mathrm{C} . P$. pentosaceus is able to grow in $\mathrm{pH}$ values between 4.5 and 8.0. The bacteria grow more stably at the more acidic $\mathrm{pH}$ range [11].

According to Tamang., et al. [20], LAB comprising of lactobacilli, pediococci and leuconostocs are the predominant microorganisms present in fermented leafy vegetables. This is in line with the work of Pederson and Albury [13] and Joshi and Sharma [14] that listed 5 species of lactic acid bacteria as important in the sauerkraut fermentation: Streptococcus faecalis, Leuconostoc mesenteroides, Lac- 


\begin{tabular}{|c|c|c|c|c|c|c|c|c|c|c|c|}
\hline No & & 2M5a & 3M7 & 7M5c & 20M5 & No & & 2M5a & 3M7 & 7M5c & 20M5 \\
\hline 1 & 0 & + & + & + & + & 26 & ESC & + & + & + & + \\
\hline 2 & GLY & - & - & - & + & 27 & SAL & + & + & + & - \\
\hline 3 & ERY & - & - & - & - & 28 & CEL & + & + & + & - \\
\hline 4 & DARA & - & - & - & - & 29 & MAL & + & + & + & + \\
\hline 5 & LARA & + & + & + & - & 30 & LAC & - & - & - & - \\
\hline 6 & RIB & + & + & + & - & 31 & MEL & - & - & - & - \\
\hline 7 & DXYL & - & - & + & - & 32 & SAC & + & + & - & + \\
\hline 8 & LXYL & - & - & - & - & 33 & TRE & + & + & + & - \\
\hline 9 & ADO & - & - & - & - & 34 & INU & + & + & - & - \\
\hline 10 & MDX & - & - & - & - & 35 & MLZ & - & - & - & - \\
\hline 11 & GAL & + & + & + & - & 36 & RAF & - & - & - & - \\
\hline 12 & GLU & + & + & + & + & 37 & AMD & - & - & - & - \\
\hline 13 & FRU & + & + & + & + & 38 & GLYG & - & - & - & - \\
\hline 14 & MNE & + & + & + & - & 39 & XLT & - & - & - & - \\
\hline 15 & SBE & - & - & - & - & 40 & GEN & + & + & + & - \\
\hline 16 & RHA & - & - & - & - & 41 & TUR & - & - & - & + \\
\hline 17 & DUL & - & - & - & - & 42 & LYX & - & - & - & - \\
\hline 18 & INO & - & - & - & - & 43 & TAG & + & + & - & - \\
\hline 19 & MAN & - & - & - & - & 44 & DFUC & - & - & - & - \\
\hline 20 & SOR & - & - & - & - & 45 & LFUC & - & - & - & - \\
\hline 21 & MDM & - & - & - & - & 46 & DARL & - & - & - & - \\
\hline 22 & MDG & - & - & - & - & 46 & LARL & - & - & - & - \\
\hline 23 & NAG & + & + & + & + & 48 & GNT & + & - & - & - \\
\hline 24 & AMY & + & + & + & - & 49 & $2 \mathrm{KG}$ & - & - & + & - \\
\hline 25 & ARB & + & + & + & - & 50 & $5 \mathrm{KG}$ & - & - & - & - \\
\hline
\end{tabular}

Table 2: Phenotypic identification of lactic acid bacteria from fermenting young muskmelon (Cucumis melon Linn) using API 50 CHL gallery kit.

tobacillus brevis, Pediococcus pentocaceus and Lactobacillus plantarum.

Traditionally fermented foods, including fermented vegetables can be a rich source of new LAB strains, with interesting functional properties and with potential applications in food industry and health [21]. Sauerkraut, fermented cucumbers, and kimchi are the most studied lactic acid fermented vegetables mainly due to their commercial importance [15].

Fermentation of fruits and vegetables can occur "spontaneously" by the natural lactic bacterial surface microflora, such as

\begin{tabular}{|l|c|c|}
\hline Colony Code & Species & ID (\%) \\
\hline 2M5a & Lactobacillus brevis 1 & 98.7 \\
\hline 3M7 & Pediococcus pentosaceus 1 & 94.5 \\
\hline 7M5c & Pediococcus pentosaceus 1 & 98.8 \\
\hline $20 \mathrm{M} 5$ & Unknown & \\
\hline
\end{tabular}

Table 3: Phenotypic identification of lactic acid bacteria from fermenting young muskmelon (Cucumis melon Linn) using API 50 CHL gallery kit. 
Lactobacillus spp, Leuconostoc spp, and Pediococcus spp.; however, the use of starter culture such as L. plantarum, L. rhamnosus, $L$. gasseri, and L. acidophilus provides consistency and reliability of performance [16]. The present research thus investigated the LAB present at different phases of fermenting young muskmelon ( mis melon Linn). The result of the study revealed that Lactobacillus brevis, and two as Pediococcus pentosaceus were the main LAB involved in the spontaneous fermentation of Cucumis melon Linn. This is in accordance with the work of [17], werein these LAB species were involved in the microbial dynamics of fermenting cucumber. These species particularly Lactobacillus plantarum and Leuconostoc mesenteroides are typical for spontaneous fermentation of vegetables [18]. Consumis melon linn interest for diverse fermented foods has increased in recent years because of the positive perception of their beneficial impact on health. Hence, there is an evident need to find novel methods and new food preservation agents from natural origins. Biopreservation, which refers to extending the shelf-life and enhancing the safety of foods using microorganisms or their metabolites, [19] would make these LAB as very good candidates as adjunct inocula [15].

\section{Conclusion and Recommendation}

The major lactic acid bacteria involved in the spontaneous fermentation of muskmelon (Cucumis melon Linn) are Lactobacillus brevis and Pediococcus pentosaceus strains. These lactic acid bacteria species can be exploited as pure starter cultures for the fermentation of other vegetables and fruits at the commercial scale.

\section{Acknowledgements}

This research is made possible by the generous support of the American People provided to the Center of Excellence on Sustainable Agricultural Intensification and Nutrition (CE SAIN) of the Royal University of Agriculture through the Feed the Future Innovation Lab for Collaborative Research on Sustainable Intensification at Kansas State University funded by the United States Agency for International Development (USAID) under Cooperative Agreement No. AID-OAA-L-14-00006. The contents are the sole responsibility of the authors and do not necessarily reflect the views of USAID or the United States Government.

\section{Bibliography}

1. Nurul SR and Asmah R. "Evaluation of antioxidant properties in fresh and pickled papaya”. International Food Research Journal 19 (2012): 1117-1124.
2. Lal G., et al. "Chutneys, sauces and pickles, preservation of fruits and vegetables". New Delhi: ICAR Publication; (2010): 235-269.

3. Choi IH., et al. "Kimchi: a fermented vegetable, improves serum lipid profiles in healthy young adults: randomized clinical trial". Journal Medical Food 16 (2013): 223-229.

4. Leroy F and de Vuyst L. "Lactic acid bacteria as functional starter cultures for the food fermentation industry". Trends Food Science Technology 15 (2004): 67-78.

5. Namasivayam SKR., et al. "Effect of media on bacteriocin production by Lactobacillus brevis and evaluation of anti-bacterial activity". Research Journal of Pharmaceutical, Biological and Chemical Sciences 5 (2014): 1129-1136.

6. Jagannath A., et al. "A two-step controlled lactic fermentation of cabbage for improved chemical and microbiological qualities". Journal Food Quality 35 (2012): 13-20.

7. Hoque M Z., et al. "Isolation, Identification and Analysis of Probiotic Properties of Lactobacillus Spp. From Selective Regional Yoghurts". World Journal of Dairy and Food Sciences 5.1 (2010): 39-46.

8. Ghanbari M., et al. "Isolation and characterization of Lactobacillus species from intestinal contents of beluga (Husohuso) and Persian sturgeon (Acipenserpersicus)". Iranian Journal of Veterinary Research, Shiraz University 10.2 (2009).

9. Sakamoto Kanta. Beer spoilage bacteria and hop resistance in Lactobacillus brevis, University of Groningen. Chapter 1 (2002): 5-6.

10. Pritchard G and Coolbear T. "The physiology and biochemistry of the proteolytic system in lactic acid bacteria". FEMS Microbiology Reviews (1993): 179-206.

11. Osmanagaoglu 0., et al. "Isolation and Characterization of Pediocin Producing Pediococcus pentosaceus Pep1 from Vacuum-Packed Sausages". Turkish Journal of Biology 25 (2001): 133-143.

12. Hu Yongjin., et al. "Effect of mixed starter cultures fermentation on the characteristics of silver carp sausages". World Journal of Microbiology and Biotechnology (2006): 1-11.

13. Noel C., et al. "Sauerkraut fermentation: New fermentation vat". Biotechnology Letter 1 (1979): 321-326. 
14. Joshi VK and Sharma S A. "Panorama of lactic acid bacterial fermentation of vegetables". International Journal of Food Fermentation Technology 2.1 (2012): 1-12.

15. El-Ghaish S., et al. "Potential use of lactic acid bacteria for reduction of allergenicity and for longer conservation of fermented foods". Trends Food Sciences Technology 22 (2011): 509516.

16. Karovicova J., et al. "The choice of strains of Lactobacillus species for the lactic acid fermentation of vegetable juices". European Food Research and Technology 1 (1999): 53-56.

17. Lennox JA and Efiuvwevwere BJO. "Microbial dynamics during cucumber fermentation". Global Research Journal of Microbiology 3.2 (2013): 13-17.

18. Tamminen M., et al. "Screening of lactic acid bacteria from fermented vegetables by carbohydrate profiling and PCR-ELISA". Letters in Applied Microbiology 39 (2004): 439-444.

19. Ross RP., et al. "Preservation and fermentation: Past, present and future". International Journal of Food Microbiology 79 (2002): 3-16.

20. Tamang JP., et al. "Identification of predominant lactic acid bacteria isolated from traditionally fermented vegetable products of the Eastern Himalayas". International Journal Food Microbiology 105 (2005): 347- 356.

21. Fred B., et al. Fermented vegetables. Food microbiology: Fundamentals and frontiers, 4th Ed. Edited by MP, Doyle and RL, Buchanan. ASM Press, Washington, D.C. (2013).

\section{Assets from publication with us}

- Prompt Acknowledgement after receiving the article

- Thorough Double blinded peer review

- Rapid Publication

- Issue of Publication Certificate

- High visibility of your Published work

Website: www.actascientific.com/

Submit Article: www.actascientific.com/submission.php

Email us: editor@actascientific.com

Contact us: +919182824667 